\title{
COMPONENTS OF COOPERATION OF CRISIS INTERVENTION
}

\author{
Michaela Jombíková Janáková1, Soňa Šrobárová
}

\begin{abstract}
Introduction: This scientific study provides an insight into the cooperation of individual social services in connection with several methods and techniques of crisis intervention. Given the diversity of the work of crisis intervention, it brings scientific results concerning the of field social workers in social and legal protection of children and social guardianship. It is the field of social workers which cooperate and manage cooperation between individual ministries and activities of individual crisis intervention services
\end{abstract}

Aim: The main objective of the research was to investigate the cooperation of social workers with other institutions and the use of diversity techniques in dealing with different types of social problems.

Methods: The research was conducted using a quantitative strategy by distributing a questionnaire of our design to social workers in Slovakia operating within the socio-legal protection and guardianship. The subject of the research was social workers of social protection. The number of respondents whose questionnaire applied to the research objectives was 56 . We used statistical analysis for the phase of data processing and evaluation.

Results: In the first research question, we investigated which social problems the respondents are facing in their practice most often. We can conclude that they often encounter problems solutions in the redevelopment of families, tackling crime, divorce, delinquency, and addictions. In the second research question we focused on with which institutions the workers cooperate in solving individual social problems.

Conclusion: Social protection workers in their everyday practice face a wide range of problems. In solving the issues, they cooperate with other professions respectively organizations. Depending on what problems social workers usually deal with, it depends not only on their experience but on their future education.

UDC Classification: 304, DOI: https://doi.org/10.12955/pss.v1.57

Keywords: Social worker, social protection and curate

\section{Introduction}

According to the National Project Support of Deinstitutionalization of Foster Care, training of employees of the department of socio-legal protection and guardianship (SPODaSK) department, including the Department of Counseling and Psychological Services (RPPS), is provided. Employees are educated in social diagnostics to improve their skills in this area. These include assessing the social situation of the client (individual, family), assessing capacities, resources and options in the context of its current functioning and social context, including assessing the functionality of interpersonal relationships and adaptability, active needs in relation to social functioning and prognosis. For the purposes of our research we can also rely on the findings of another representative research carried out by Špániková (2018). Although the research was primarily focused on the creation and functioning of partner networks of organizations within the framework of penitentiary and post-penitentiary care and the need for education of individual professions in networks, the basic postulates of research are equally valid for networking in the areas of our cooperation and social curators from the ÚPSVR $(\mathrm{n}=$ 38) who also work with families as a target group. Based on the model of social roles (Fransell, 1982), the author perceives their balance in the social worker as a basic precondition for the complexity of his personality. The balance of social roles in a social worker is conditioned by ensuring the deepening of knowledge and skills in continuous education. Targeted education, according to Špániková, allows the cooperation of social worker in partner networks not only to build on intuitive empirical experience, but to address the issue with regard to the needs of their own practice (positively influencing the results of their activities) (Špániková, 2018, p. 87). Another area of education is planning social work with the child's family, teamwork and networking. The priority is to keep the children in the natural family environment and return children back to the natural family environment when they have been excluded from it. Education aims are to improve skills in planning social work with families of a child with persons who perform actions SPODaSK and teamwork intervening entities. Intervention in a natural family environment and planning social work with the child's family can help prevent crises situation in the family, and find resources to support families in providing care and education of children and help prevent exclusion of the child from his family and entrusted to foster care. Equally important is the planning of social work with the family of the child who has returned to his / her family from foster care and promoting the sustainability of the child's return to the biological family.

\footnotetext{
${ }^{1}$ Catholic University of Ruzomberok, Faculty of Education, Ruzomberok, Slovakia, michaela.janakova@ku.sk

${ }^{2}$ Catholic University of Ruzomberok, Faculty of Education, Ruzomberok, Slovakia, sona.srobarova@ku.sk
} 
As reported byŠpatenková (2004), crisis intervention consists of various forms of aid, aimed at returning an individual to his / her psychological balance disrupted by a critical life event. Crisis intervention includes mainly psychological, medical, social and legal assistance. In the framework of social assistance, crisis intervention is understood as an action aimed at immediate social intervention aimed at those who are in an acute crisis situation.

According to Act no. 448/2008 on social services, social service is a professional activity, service activity or other activity or set of these activities, which are focused in on the solution to a social crisis situation of a natural person and family. Crisis intervention social services are provided when there is an unfavorable social situation of a natural person. These services may be of a low-threshold nature. Crisis intervention services include:

- Field Social Service Crisis Intervention,

- Provision of social services in facilities - low threshold day center, integration center, community center, dormitory, shelter, half-home, emergency housing, low-threshold social service for children and family

Field social services carried out by field social workers in crisis intervention is provided to a natural person who finds himself in an unfavorable situation and whose content is an activity aimed at searching for such natural persons, professional activities, service activities and other activities aimed primarily at performing a preventive activity, providing social counseling, social rehabilitation, assisting in the exercise of rights and legitimate interests, and creating conditions for the provision of food (Kozoň, 2013). The social worker should adhere to the principles of crisis intervention, which are simplicity, conciseness, innovation, pragmatism, accessibility, immediacy and anticipating. Every person who finds himself in crisis is unable to respond to more difficult stimuli. A well-managed postintervention service is also based on directing the client to another support institution if necessary.

\section{Methods}

Cooperation of social workers in dealing with social problems. The main objective of the research was to investigate the cooperation of social workers with other institutions and the use of diversity techniques in dealing with different types of social problems.

The research was conducted using a quantitative strategy by distributing a questionnaire of our design to social workers in Slovakia operating within the socio-legal protection and guardianship.

We used statistical analysis for the phase of data processing and evaluation.

The research took place in 2019.

\section{Sample}

Respondents ranged in age from 21 to 60 years. There were 19 respondents in the group of 21 to 30 years old, there were 25 respondents in the group of 31 to 40 years old, there were 21 respondents in the group of 41 to 50 years old and 11 respondents in the group of 51 to 60 years old.

The number of respondents whose questionnaire applied to the research objectives was 56 .

The object of the research: social workers of social protection

\section{Results}

Table 1 shows the results of the correlation analysis between addressing various social issues and institutions with whom social worker cooperates. We can conclude that respondents:

- Addressing domestic violence, cooperate to a greater extent with the police $(r=0.421, p=$ $0.011)$.

- Addressing remediation of families cooperate to a greater extent with the police, schools and health institutions $(\mathrm{r}=0.413, \mathrm{p}=0.012, \mathrm{r}=370, \mathrm{p}=0.024, \mathrm{r}=0.422, \mathrm{p}=0.045)$.

- dealingwith divorces cooperate to a greater extent with the police $(r=0.494, p=0.002)$.

- dealingwith homelessness cooperate to a greater extent with the school and the psychologist ( $\mathrm{r}$ $=0.383, \mathrm{p}=0.020, \mathrm{r}=0.318, \mathrm{p}=0.047$ ).

- solving crimes, they cooperate to a greater extent with the school $(r=0.480, p=0.004)$.

- dealing with suicide, cooperate to a greater extent with the police $(r=0.387, p=0.018, r=$ $0.405, \mathrm{r}=0.050)$.

- working with victims of crime, they cooperate to a greater extent with the police $(r=0.458, p$ $=0.006$ ). 


\begin{tabular}{|c|c|c|c|c|c|c|}
\hline \multirow[b]{2}{*}{ Social Problem } & \multirow[b]{2}{*}{ Statistical Indicator } & \multicolumn{5}{|c|}{ Cooperating Institution / profession } \\
\hline & & Fire brigade & Police & School & $\begin{array}{l}\text { Medical } \\
\text { equipment }\end{array}$ & Psychologist \\
\hline \multirow{3}{*}{$\begin{array}{l}\text { Domestic } \\
\text { violence }\end{array}$} & Correlation Coefficient & 0.083 & $421 *$ & 0.192 & 0.014 & 0.217 \\
\hline & Sig. (2-tailed) & 0.707 & 0.011 & 0.381 & 0.951 & 0.32 \\
\hline & $\mathrm{N}$ & 23 & 23 & 23 & 23 & 23 \\
\hline \multirow{3}{*}{$\begin{array}{c}\text { CAN } \\
\text { Syndrome }^{3}\end{array}$} & Correlation Coefficient & -0.017 & 0.161 & 0.015 & -0.151 & -0.161 \\
\hline & Sig. (2-tailed) & 0.94 & 0.464 & 0.945 & 0.492 & 0.462 \\
\hline & $\mathrm{N}$ & 23 & 23 & 23 & 23 & 23 \\
\hline \multirow{3}{*}{$\begin{array}{l}\text { Work with } \\
\text { Survivors }\end{array}$} & Correlation Coefficient & 0.24 & 0.062 & 0.177 & 0.249 & -0.047 \\
\hline & Sig. (2-tailed) & 0.27 & 0.78 & 0.419 & 0.251 & 0.833 \\
\hline & $\mathrm{N}$ & 23 & 23 & 23 & 23 & 23 \\
\hline \multirow{3}{*}{$\begin{array}{l}\text { Redevelopment } \\
\text { families }\end{array}$} & Correlation Coefficient & 0.182 & $413 *$ & $470 *$ & $422 *$ & 0.315 \\
\hline & Sig. (2-tailed) & 0.405 & 0.012 & 0.024 & 0.045 & 0.143 \\
\hline & $\mathrm{N}$ & 23 & 23 & 23 & 23 & 23 \\
\hline \multirow{3}{*}{$\begin{array}{l}\text { Suicidalexperim } \\
\text { ents }\end{array}$} & Correlation Coefficient & 0.06 & 0.092 & 0.193 & 0.208 & -0.114 \\
\hline & Sig. (2-tailed) & 0.786 & 0.675 & 0.378 & 0.341 & 0.606 \\
\hline & $\mathrm{N}$ & 23 & 23 & 23 & 23 & 23 \\
\hline \multirow{3}{*}{ Self- harm } & Correlation Coefficient & 0.051 & 0.21 & 0.311 & 0.227 & 0.105 \\
\hline & Sig. (2-tailed) & 0.817 & 0.337 & 0.148 & 0.297 & 0.633 \\
\hline & $\mathrm{N}$ & 23 & 23 & 23 & 23 & 23 \\
\hline \multirow{3}{*}{ Divorce } & Correlation Coefficient & 0.071 & $594 * *$ & 0.237 & 0.255 & 0.142 \\
\hline & Sig. (2-tailed) & 0.749 & 0.003 & 0.276 & 0.241 & 0.518 \\
\hline & $\mathrm{N}$ & 23 & 23 & 23 & 23 & 23 \\
\hline \multirow{3}{*}{ Infidelity } & Correlation Coefficient & 0.1 & 0.363 & 0.265 & -0.051 & 0.108 \\
\hline & Sig. (2-tailed) & 0.651 & 0.089 & 0.222 & 0.817 & 0.623 \\
\hline & $\mathrm{N}$ & 23 & 23 & 23 & 23 & 23 \\
\hline \multirow{3}{*}{ Home loss } & Correlation Coefficient & 0.385 & 0.322 & $483 *$ & 0.283 & $418 *$ \\
\hline & Sig. (2-tailed) & 0.07 & 0.134 & 0.02 & 0.191 & 0.047 \\
\hline & $\mathrm{N}$ & 23 & 23 & 23 & 23 & 23 \\
\hline \multirow{3}{*}{ Crime rate } & Correlation Coefficient & 0.371 & 0.275 & $580 * *$ & 0.41 & 0.379 \\
\hline & Sig. (2-tailed) & 0.082 & 0.205 & 0.004 & 0.052 & 0.074 \\
\hline & $\mathrm{N}$ & 23 & 23 & 23 & 23 & 23 \\
\hline \multirow{3}{*}{ Delinquency } & Correlation Coefficient & 0.236 & -0.003 & 0.218 & 0.219 & -0.013 \\
\hline & Sig. (2-tailed) & 0.277 & 0.988 & 0.318 & 0.316 & 0.954 \\
\hline & $\mathrm{N}$ & 23 & 23 & 23 & 23 & 23 \\
\hline \multirow{3}{*}{ Suicide } & Correlation Coefficient & 0.337 & $487 *$ & 0.297 & 0.163 & 0.231 \\
\hline & Sig. (2-tailed) & 0.115 & 0.018 & 0.169 & 0.459 & 0.29 \\
\hline & $\mathrm{N}$ & 23 & 23 & 23 & 23 & 23 \\
\hline \multirow{3}{*}{ Child exclusion } & Correlation Coefficient & 0.125 & 0.33 & 0.165 & 0.335 & 0.115 \\
\hline & Sig. (2-tailed) & 0.571 & 0.124 & 0.452 & 0.119 & 0.601 \\
\hline & $\mathrm{N}$ & 23 & 23 & 23 & 23 & 23 \\
\hline \multirow{3}{*}{ Loss } & Correlation Coefficient & 0.106 & 0.312 & 0.232 & 0.108 & 0.332 \\
\hline & Sig. (2-tailed) & 0.632 & 0.147 & 0.286 & 0.623 & 0.122 \\
\hline & $\mathrm{N}$ & 23 & 23 & 23 & 23 & 23 \\
\hline \multirow{3}{*}{ Addictions } & Correlation Coefficient & 0.108 & 0.301 & 0.308 & 0.217 & 0.212 \\
\hline & Sig. (2-tailed) & 0.625 & 0.163 & 0.152 & 0.32 & 0.332 \\
\hline & $\mathrm{N}$ & 23 & 23 & 23 & 23 & 23 \\
\hline \multirow{3}{*}{$\begin{array}{l}\text { Victims of } \\
\text { crime }\end{array}$} & Correlation Coefficient & 0.159 & $558 * *$ & 0.291 & 0.308 & 0.121 \\
\hline & Sig. (2-tailed) & 0.47 & 0.006 & 0.179 & 0.153 & 0.583 \\
\hline & $\mathrm{N}$ & 23 & 23 & 23 & 23 & 23 \\
\hline
\end{tabular}

Research question: Is there a correlation between the type of crisis intervention services, in which respondents work and solving individual social problems?

Correlation analysis between the type of service of crisis intervention and solving individual social problems brings the following findings.

We can conclude that:

-respondents working in crisis housing services in dealing with the CAN syndrome $(r=0.525)$ and suicides $(r=0.339)$.

${ }^{3}$ Syndrom, child abuse and child neglect. 
-respondents working outdoor in the field of crisis services dealing with suicidal attempts $(r=0.259)$, self-harm $(r=0.381)$, divorce $(r=0.248)$, infidelity $(r=0.338)$, homelessness $(r=0.351)$, crime $(r=$ $0.333)$, delinquency $(\mathrm{r}=0.342)$, the material, functional, relational, and role-intrapsychic loss $(\mathrm{r}=$ $0.241)$, and addictions $(\mathrm{r}=0.44)$.

- respondents working in emergency services in the natural family environment when dealing with domestic violence $(r=0.332)$, CAN syndrome $(r=0.424)$, rehabilitation of families $(r=0.425)$, suicidal attempts $(r=0.307)$, self-harm $(r=0.278)$, distribution $(r=0.253)$, infidelity $(r=0.292)$, homelessness $(r=0.351)$, delinquency $(r=0.254)$, child exclusion $(r=234)$, physical, functional, relational, intrapsychic and role-loss $(r=0.388)$, addiction $(r=0.331)$ and victimis of crime $(r=$ $0.374)$.

-respondents working in telephone emergency services dealing with domestic violence $(r=0.346)$, CAN syndrome $(r=0.301)$, working with survivors $(r=0.257)$, suicidal attempts $(r=0.343)$, selfharm $(r=0.278)$, material, functional, relational, intrapsychic and role-loss $(r=0.305)$ and victimization $(\mathrm{r}=0.342)$.

-respondents working for online chat in dealing with domestic violence $(r=0.303)$, CAN syndrome $(r$ $=0.303)$, working with survivors $(r=0.257384$ suicidal attempts $(r=0.235)$, infidelity $(r=0.253)$ and victims of crime $(r=0.346)$.

\section{Discussion}

In the first research question, we investigated which social problems the respondents are facing in their practice most often. We can conclude that most often social workers encounter problems in development of families, tackling crime, divorce, delinquency, and addictions. Occasionally they also encounter the removal of the child from the natural family environment, loss of home, CAN syndrome, infidelity, domestic violence, material, functional, relationship, intrapsychic and role loss, victims of crime, and self-harm. Rarely are they faced with working with survivors and the social problem of suicide. Social issues, in our view, are closely linked with practice. Depending on what problems social workers usually deal with, they will decide on their following future educational plan.

Social protection workers in their everyday practice are facing a wide range of problems. In solving these issues, they cooperate with other professions respectively organizations. It is a difficult job full of challenges and needs for the further education of social workers. This is a factor that can be a decisive or limiting factor in the quality of the provided services.

In terms of the structure of workers, however, age may be a risk factor - education has a different value for a younger worker and an older worker (Špániková, 2013).

For the reasons set out above, we have therefore ascertained in the second research question with which institutions the workers cooperate in solving individual social problems. We found that if SPODaSK field social workers deal with the problem of domestic violence and working with survivors, they cooperate more with firefighters, if they deal with delinquency they cooperate more with school and if they deal with suicides, they cooperate more with healthcare providers. Social workers and cooperation with institutions mean that, according to the social problem, the institution with which cooperation is important is chosen. E.g. when dealing with delinquency, the field social worker needs to contact the school.

Furthermore, we found that when social workers working with survivors and addressing infidelity, they often cooperate with firefighters. They cooperate with firefighters and school when they deal with suicide attempts.

In the case of family rehabilitation, they cooperate with a psychologist, with whom they also cooperate in the case of the exclusion of the child from the natural family environment, but in addition to the psychologist, this social problem also cooperates with healthcare facilities. If they deal with crime and delinquency, they cooperate to a greater extent with the police. They cooperate more closely with the police and healthcare facilities when dealing with people with addictions.

Finally, if the respondents chose the "other" option in the questionnaire (mainly guardian ad litem, social workers, and psychologists), if they deal with domestic violence, suicide, work with victims of crime or deal with divorce, they significantly more often cooperate with the police, school and healthcare facilities. 
I do not understand this sentence.If they deal with the loss of home more often, they cooperate with school and psychologists and if they deal with crime more often they cooperate with the school.

\section{Strengths and Limitations}

The research was focused on the population of the Slovak Republic, therefore the results of the research are formulated for application only in the given area. The research results point to the need for educational activities aimed at improving skills in the field of social diagnostics, in order to assess the client's social situation in relation to social functioning and his prognosis.

\section{Conclusion}

Important findings were that those respondents who work in crisis housing services more often deal with CAN syndrome and suicide. Those working in field crisis services often deal with suicidal attempts, self-harm, crime, infidelity, home loss, delinquency, material, functional, relationship, intrapsychic and role loss and dependence. Respondents working in crisis services in a natural family environment are more likely to address domestic violence, CAN syndrome, family remediation, suicide attempts, self-harm, divorce, infidelity, loss of home, delinquency, exclusion of a child from natural family environment, material, functional, relationship, intrapsychic and role loss, addiction, and work with crime victims. Those working in telephone crisis services are more likely to deal with domestic violence or CAN syndrome, work with survivors, deal with suicidal attempts, self-harm, material, functional, relationship, intrapsychic and role loss, and work with crime victims. Finally, those who work on chat more often deal with domestic violence, CAN syndrome, work with survivors, deal with suicide attempts, infidelity, and work with crime victims. As we can see from the above, the types of crisis intervention services address social problems.

\section{References}

Bachyncová Giertliová, J., Hardy, J. (2012). Metódy sociálnej práce s rodinou. [Methods of Social Work with Family]. Bratislava St. Wenceslas University of Health and Social Work Elizabeth in Bratislava.

Karkošková, S. (2017). Znalecké posudzovanie domáceho násilia v kontexte poručenských sporov o deti [Expert assessment of domestic violence in the context of child litigation]. Bratislava: Labor and Family Research Institute.

Kovacic, V. (2002).) Model funkčnej rodiny a formovania osobnosti [Functional family model and personality formation]. Prague. Proconsul.

Kozoň, A. et al. (2013). Etické otázky socializácie: sociálnej práce a príbuzných vedných disciplín [Ethical Issues of Socialization: Social Work and Related Disciplines Science]. Trenčín: Society for Social Integration in the Slovak Republic. Špániková, M. (2013). Age management comme façon de solution de la traduction d'emploi des employés au-dessus de 50 ans I. [Age Management as a Way of Dealing with the Issue of the Employment of Workers Over 50 Years of Age I]. Revue Internationale des Sciences Humaines et naturelles. Friborg Association internationale Sciences, Education, Cultures, Traditions, 2013. Année 3 Num. 2 p. 51-64. 2013. ISSN 2235-2007.

Špániková, M. (2018). Penitenciárna a postpenitenciárna starostlivost' - d'alšie vzdelávanie sociálnych pracovníkov. [Penitentiary and Probation support - further education of social workers]. Ružomberok VERBUM, 2018. 127 p. ISBN 978 80-561-0626-6.

Špatenková, N. et al. (2004). Krizová intervence pro praxi[Crisis intervention for practice]. Prague: Grada Publishing, Inc. Špatenková, M. (2017). Krize a krizová intervence [Crisis and crisis intervention]. Prague: Grada Publishing, Inc. Licensing Act), as amended.

Law no. 305/2005 Coll. the socio-legal protection and social guardianship and on amendments to certain laws [ACT NO. 305/2005 Coll. (On socio-legal protection and social curator and Amendments to Certain Acts)]

Law no. 448/2008 Coll SR of 30 October 2008 on social services and amending Act no. 455/1991 Coll. on Trades (Trade Act), as amended [Act of the National Council of the Slovak Republic no. 448/2008 Coll of the SR of 30 October 2008 on social services and amending and supplementing Act no. 455/1991 Coll. on Trade Licensing Trade] 